\title{
3 RELIGIOUS PLURALISM AND COHABITATION IN ETHIOPIA: SOME CRITICAL NOTES
}

\section{Theodros Teklu ${ }^{1}$}

\section{INTRODUCTION}

Religious diversity is a typical feature of many societies, including African ones. Religious identities are, arguably, shaped not only by societies" "heritage" (including cultural, religious, legal and historical dimensions), but also by social developments. By social developments, I mean those global processes that enter the subjectivities of Africans, in general, and Ethiopians, in particular, such as the socialist movement, neoliberal order, and Islamic radicalisation or "universal" declarations of human rights. Drawing on contemporary social developments that shape the religious identities of Ethiopians, this essay discusses radical religious imaginations that simultaneously institute identity and obliterate the invisible heritage, understood as the diverse ways in which different religious identities, mainly Islam and Christianity, developed together with the sense of mutual respect.

Although a competitive relationship should not be established between heritage and social development, because of their overlapping spheres and potential for synergy, it is important to note that the tension between them can at times be non-constructive, even devastating. In studying the Ethiopian experience, one can observe both. The purpose of this essay is not to offer a full-fledged account of radical religious and political imaginations in Ethiopia. It is rather to present some ideas developed by social theorists, sociologists, anthropologists and historians, which may prove profitable for conceptually reflecting on religious pluralism and heritage in light of legal and social developments in Ethiopia. Consequently, this study aims at encouraging attentive reflection on the current tension in Christian-Muslim relations towards paving the way for an ethos of cohabitation and responsibility.

Cohabitation can be captured by the semantic range of the Latin words habito, habitare, habitavi, and habitatus that mean "inhabit, dwell" and also "live, stay". ${ }^{2}$ The immediacy or elemental nature of cohabitation, which is primordial to any form of contract or covenant, has a great significance to consider the habitat as a common (Gk koinos) fostering human togetherness and fellowship (Gk koinonia). My use of the concept has an affinity with the use of the term by philosophers such as Judith Butler and Charles Taylor who appeal not to the

1 Lecturer in Philosophical Theology and Ethics, Ethiopian Graduate School of Theology.

2 Online at: http://latin-dictionary.net/definition/21820/habito-habitare-habitavihabitatus 


\section{Religion, Pluralism and Heritage in Ethiopia}

notion of toleration but "cohabitation". ${ }^{3}$ Cohabitation implies that all people are cohabitants on earth, and that "We are given to each other. We can't choose." More on this later.

To this end, I shall focus on imaginations at the intersection of local and global processes that shape the subjectivities of Ethiopians and their implications for religious freedom, rights and responsibilities. I shall begin by delineating the contemporary religious tension in Ethiopia by drawing attention to the relationship between the two main religions in the country - Christianity (63\%) and Islam (34\%). This part of the discussion aims at explaining how religious identities are being (re)constructed - between heritage and social development - in a manner that advances religious cleavages. Second, I will critically examine the syntax (grammar) of the public and the crisis of civility within the Ethiopian context. By civility, I mean the culture of mutual recognition and respect. ${ }^{6}$ Here, I will analyse the Muslim narrative of marginalisation and victimisation contra the narrative of peaceful coexistence and tolerance that has dominated public discourse in Ethiopia. I will further develop the analysis by focusing on the crisis of civility manifested by the public visibility of religion. Before concluding, I will emphasise the need for a moral pedagogy that accentuates the imperative of peaceful and harmonious cohabitation as an antidote to the "mad dream of a world without others". ${ }^{7}$

\section{RELIGIOUS PLURALISM BETWEEN HERITAGE AND SOCIAL DEVELOPMENT}

As far as the question of religious ... equality is concerned, the result is a mixed affair. Islam, one of the oldest religions in the country, has come to enjoy since 1975 the kind of recognition and respect it deserves. Nevertheless, one could notice a feeling of "It is getting too far" on the part of the Christians and "It is only the beginning" on the part of Muslims. Wise and prudent leadership is required on both sides

3 Butler J. 2011. "Is Judaism Zionism?", in Mendieta E and Van Antwerpen J (eds). The Power of Religion in the Public Sphere. New York: Columbia University Press, 71-91.

4 Cf. The words of the well-known philosopher, Charles Taylor; Butler J, Habermas J, Taylor C and West C. "Concluding Discussion”, in Mendieta E and Van Antwerpen J, 111.

5 Based on Census 2007, Orthodox (43.5\%), Muslim (33.9\%), Protestant (18.6\%), traditional (2.6\%), Catholic $(0.7 \%)$, other $(0.7 \%)$; cf. Central Statistical Agency, "Population and Housing Census Report-Country - 2007". Online at: http:// www.csa.gov.et/

6 Charles Taylor refers to civility as the culture of "human rights, equality and non-discrimination and democracy", which are norms around which democratic societies are organised. See Petersen HS. 2013. "Political Engagement of Historic Churches in Eastern Africa", Swedish Missiological Themes, 101:67-106.

7 Mbembe A. 2002. "African Modes of Self-Writing", Public Culture 14(1):252. 
to make sure that these two old religions would not abandon their tradition of mutual tolerance. ${ }^{8}$

Taking our cue from this passage from one of the most prominent Ethiopian historians, Bahru Zewde, we recognise that religious equality and the question of entitlement are contested issues in Ethiopian history. Muslims feel that the Orthodox have been privileged throughout history and consider it relevant to demand plots of land, for example, to construct mosques. As the above quote establishes, the current situation is characterised by a tension that has the potential to intensify polarisation between Christianity and Islam in Ethiopia. This, in turn, corresponds to the tension between heritage and social development. First, the fact that Islam has gained recognition reflects that remarkable social development has taken place in Ethiopia; and second, the erosion of the culture of mutual respect signifies the obliteration of heritage - "pan-Ethiopian traits", as will be explained below. Although subject to contradictory interpretations, both the culture of recognition and respect, as well as legal recognition, are part of the historical reality of Ethiopia.

A cursory review of the scholarly discussion reveals academic arguments for the peaceful introduction of Islam into historic Ethiopia and its subsequent indigenisation, in contrast to other scholarly voices emphasising Muslim marginalisation and victimisation. The latter perspective utilises the metaphor of a "Christian island" a metaphor ostensibly depicting historic Ethiopia as a Christian country surrounded by Muslims - to make a case for the historical victimisation of Muslims. ${ }^{9}$ Along these lines this metaphor is deployed to reconstruct Ethiopian history as one characterised by a fault-line and power asymmetry between Christianity and Islam. ${ }^{10}$ Given the complexity of "Ethiopia" and the various forms the state has taken throughout history - and more specifically, the modern (re)construction of the Ethiopian State - such trends can be rendered problematic.

Contra such a reductive account of history, one may draw attention to how Ethiopians developed as a people. To be sure, it was not merely because of their historical subjection to a common law under the single polity of Ethiopia that Ethiopians - of diverse religious backgrounds - developed as a people. Indeed, there have been micro-levels of social relations that made possible the interaction of Ethiopians across ethnic and religious divides. As Donald Levine,

8 Zewde B. 2008. Society, State and History. Addis Ababa: Addis Ababa University Press, 353.

9 Østebø T. 2010. "Islamism in the Horn of Africa: Assessing Ideology, Actors, and Objectives". CMI Working Paper 2:52. The idea of Ethiopia being, or depicted as, a "Christian island" might show how it countered attacks of Islamic intrusion (e.g. external enemies such as Turks and Mahdist Sudan), but not necessarily internal Muslim sultanates - without suggesting that there was always a peaceful relationship between them.

10 Desplat P. 2005. "The Articulation of Religious Identities and Their Boundaries in Ethiopia: Labelling Difference and Processes of Contextualization in Islam", Journal of Religion in Africa 35(4):482-505, 486. 
rightly, points out, there are pan-Ethiopian traits that cut across ethnic and religious groups in Ethiopia: "beliefs about supernatural beings; ritual practices; food taboos; the cult of masculinity; aspects of social organization; insignia of ranks; and customs regarding personal status and the home." 11 According to this view, Ethiopia can be considered a "culture area" that fosters inter-religious interaction. Religions - Christianity, Islam and Judaism - have long coexisted and indigenised in Ethiopia developing common features over time. It suffices here to mention common traits between both Islam and Christianity such as views on religious conversion, veneration of saints, and pilgrimages. ${ }^{12}$

Underlying the above-stated convergent histories of these major religions are expressions of a heritage of peaceful coexistence and mutual respect. ${ }^{13}$ Levine notes the substantial proof of a greater degree of tolerance and mutual respect that has developed as a distinctive feature of Ethiopian religions. ${ }^{14}$ Arguably, this is not possible without convergent histories and the development of a commonly-held ethos of togetherness. Exploring the frontiers of commonality between these religious groups could be an interesting and important academic exercise. ${ }^{15}$

To argue for cultural and religious coexistence, however, one should not whitewash the grimier historical realities. ${ }^{16}$ The opening quote from Bahru Zewde's work indicates the efforts of previous and current governments, which have sought to bring constitutional remedies in order to address past imbalances which largely resulted from the status of the Ethiopian Orthodox Tewahedo

11 Levine D. 1974. Greater Ethiopia: The Evolution of a Multiethnic Society. Chicago; London: University of Chicago Press, 47.

12 Østebø T. 2007. "The Question of Becoming: Islamic Reform-Movements in Contemporary Ethiopia", Journal of Religion in Africa 38(4):416-446. Levine, Greater Ethiopia, 44.

13 Levine D. 2007. "Notes on Ethiopia's Distinctive Religious Heritage", Ethiopian Review. Online at: http://www.ethiopianreview.com

14 See Levine, "Notes on Ethiopia's Distinctive Religious Heritage".

15 The work of Meron Zeleke could be exemplary in this regard. Based on ethnographic research done on the former centres of Sufi and the courts of sheikhs, Meron Zeleke explicates the various kinds and aspects of rituals that foster conflict resolution and peaceful coexistence at the micro-level of existence integrating people across ethnic and religious cleavages. See Zeleke M. 2010. "The former Sufi Centers of Learning and Their Contemporary Courts", Journal of Religion, Conflict \& Peace 3(2):1-34. Online at: http://connection.ebscohost. com/c/articles/66621024/former-sufi-centers-learning-their-contemporary-courts. Works that expound the syncretistic nature of religion sometimes can positively challenge ideas of purity and exclusivity, cf. Debele SB. 2009. Hybridization and Coexistence of Qallu Cabsa Institution with Orthodox Christianity in Debrelibanos Area, Master's Thesis, Institute of Ethiopian Studies, Addis Ababa University.

16 Freedom and rights discourse is a modern-day problem that should not be stretched beyond the emergence of territorially defined nation-states aiming at the total control of populations which, depending on the specific context, is a modern phenomenon that goes back only to a few centuries or decades. 
Church as the state church until 1974. ${ }^{17}$ The following articles enshrined in the current Constitution of Federal Democractic Republic of Ethiopia adopted in 1995 (ratification in 1994) ${ }^{18}$ are pertinent to religious freedom: "Article 11: " 1 . State and religion are separate. 2 . There shall be no state religion. 3 . The state shall not interfere in religious matters and religion shall not interfere in state matters." This article is rightly considered as one that guarantees the secular status of the state. Of course, this kind of secularisation can be understood as secularisation for the sake of religion because (a) the absence of a state church implies the equality of all religions and (b) the separation of religion and state safeguards the autonomy of the two (the freedom of religion is further elaborated in Article 27:1-5). ${ }^{19}$ From this perspective, such secularisation seems to be more "procedural" rather than "programmatic" and has its own merits for achieving what Rajeev Bhargava calls "principled distance" between religion and the state. ${ }^{20}$ State neutrality however has its own advantages in religiously diverse countries such as Ethiopia.

Such constitutional reforms are not only manifestations of internal phenomena, but also social development that insinuates global processes. Accordingly, the enactment of equality and juridical recognition in Ethiopia are results of internal processes intersecting with global processes such as socialism. Indisputably, "the socio-political history of Ethiopia had seen much Marxist thinking immersed into its intellectual self-understanding." ${ }^{21}$ Hence, the above articles are reminiscent of both the fruit of egalitarian socialist ideals and "universal" declarations of human rights. But, this should not suggest that peaceful religious cohabitation and

17 At this juncture, it is important to note that the imbalance was not particular to Islam but, as a matter of fact, Protestant Christianity was highly persecuted as outlandish. See Constitution of the Federal Democratic Republic of Ethiopia, 1994.

18 Cf. The Ethiopian Constitution (1994) and (1984).

19 Article 27: "1. Everyone has the right to freedom of thought, conscience and religion. This right shall include the freedom to hold or to adopt a religion or belief of his choice, and the freedom, either individually or in community with others, and in public or private, to manifest his religion or belief in worship, observance, practice and teaching. 2. Without prejudice to the provisions of subArticle 2 of Article 90, believers may establish institutions of religious education and administration in order to propagate and organize their religion. 3 . No one shall be subject to coercion or other means which would restrict or prevent his freedom to hold a belief of his choice. 4. Parents and legal guardians have the right to bring up their children ensuring their religious and moral education in conformity with their own convictions. 5. Freedom to express or manifest one's religion or belief may be subject only to such limitations are prescribed by law and are necessary to protect public safety, peace, health, education, public morality or the fundamental rights and freedoms of others, and to ensure the independence of the state from religion."

20 Williams R. 2008. "Secularism, Faith and Freedom", in Ward G and Hoelzl M (eds). The New Visibility of Religion: Studies in Religion and Cultural Hermeneutics. London \& New York: Continuum, 48; Taylor C. 2011. “Why We Need a Radical Redefinition of Secularism", in Mendieta and Van Antwerpen, 34.

21 Teklu T. 2014. The Politics of Metanoia: Towards a Post-Nationalistic Political Theology in Ethiopia. Peter Lang GmbH, Internationaler Verlag der Wissenschaften, 85. 


\section{Religion, Pluralism and Heritage in Ethiopia}

mutual respect are purely outcomes of the legal recognition of religions. As the scholarly perspectives indicate in the above discussion, before the drafting and implementation of legal charters, there were already-existing practices of mutual recognition - albeit to differing degrees and despite some occasional challenges that disturb mutuality.

Granted, juridical recognition has its own benefits; thus, the freedoms and rights enshrined in the Ethiopian Constitution must be accompanied by good governance that ensures the rule of law. But this needs to match cultural values that make the implementation of the rules possible. Ethiopians of various religious affiliations have yet to mature in this respect. Religious identities in Ethiopia are held in the tension between heritage and social development. What further complicates the Ethiopian case at this juncture in history is the presence of another phenomenon of global processes - that is, Islamic identity discourse informed by Islamic reformism and, arguably, radicalism. We now look at this in greater detail.

\section{THE CRISIS OF CIVILITY AND THE SYNTAX OF THE PUBLIC}

As the foregoing discussion attempted to briefly demonstrate, a tension between heritage and social development characterises religious identities in Ethiopia. In what follows, I wish to spell out the tension in terms of the crisis of civility, in particular, the discursive disrespect as manifest incivility. In Ethiopia, since such a crisis is interlinked with the narrative construction of identities and their enactment in public, I will discuss the narrative of Muslim marginalisation and victimisation. An important caveat at this stage is that: (a) I do not claim to establish a unilinear causal relation between the narrative, which I am going to analyse, and discursive disrespect in the public sphere since the influence likely goes in both directions and (b) the fact that I will primarily deal with a Muslim narrative should not give the impression that there are no problems with other narratives, Christian or otherwise.

\section{The narrative of Muslim marginalisation and victimisation}

Debates over the meaning of the past and ways of taking the past forward have dominated political discourse in Ethiopia for some decades now. In the wake of the upsurge of ethnic sentience which resonates in ethno-nationalist historiography, Muslim scholars and popular writers have embarked on a project of reconstructing the history of Islam in Ethiopia. ${ }^{22}$ Such new sensibility has led to the questioning of the "conventional" idea that there has been

22 Crummey D. 2001. "Ethiopian Historiography in the Latter Half of the Twentieth Century: A North American Perspective", Journal of Ethiopian Studies 34 (Special Issue):7-24. 
a peaceful coexistence between Christians and Muslims in Ethiopia. ${ }^{23}$ As Dereje Feyissa notes, the idiom of coexistence is already exhausted because of its susceptibility to contrary interpretations: the Ethiopian Orthodox Tewahedo Church is said to understand it as accommodation (how Christian Ethiopia historically welcomed Muslims), while Muslims opt to understand it as forbearance (how Muslims endured the historical marginalisation and victimisation under Ethiopian Christian rulers). ${ }^{24}$ In this respect, the work of Ahmad Hussien, the late professor of history at the Addis Ababa University, can be a good representative that demonstrates this trend. I shall briefly examine his work, which offers a narrative construction of Ethiopian Muslim identity, and will forward some critical remarks.

First, the narrative construction starts by drawing attention to the hijrah - the emigration of persecuted followers of Muhammad from Mecca to seek asylum in Axum in 615 AD - in order to assert that Islam, in Ethiopia, is as old as Islam itself. The discourse proceeds to substantiate the presence of peaceful coexistence in the period following hijrah, thereby constructing an idealised religious past, which highlights not only the accommodation of Islam, but also a joyous embrace of Islam, symbolically illustrated by the conversion of the Axumite Christian king Nejashi to Islam. ${ }^{25}$ The narrative depicts this period as the Golden Age. Until the thirteenth century peaceful coexistence continued, but the factors that contributed to the peaceful coexistence are never elaborated - in fact, the possibility of a development of pan-Ethiopian traits are rejected.

Second, the period following the Golden Age - from the thirteenth to the sixteenth century - is characterised by conflict between the Christian kingdom of Ethiopia and the Muslim sultanates. This period is considered to have contributed to the resurgence and military resistance against the Christian kingdom by Muslim sultanates of Ifat and Adāl with the climax of Imām Ahmad b. Ibrāhīm (nicknamed, Ahmad Grañ, meaning Ahmad the left-handed) (1506-1543), who attacked the Christian kingdom of Ethiopia, forcefully converting Christians to Muslims and destroying churches and manuscripts. This conflict is said to have oscillated with some Islamic victories, but ultimately the Muslims were defeated, leading to a subsequent period of the pacification of Muslims, who "seem to have accepted their subordinate position as part of the natural order of things." ${ }^{26}$ It is due to the brutality of Christian Ethiopia's conquest of Muslims that the Muslim subject has been exposed to a politically exploitative system. The narrative holds Ethiopia's hostility and brutality

23 Hussein A. 2006. "Coexistence and/or confrontation? Towards a reappraisal of Christian-Muslim encounter in contemporary Ethiopia," Journal of Religion in Africa 36:4-22.

24 Feyissa D. "Accommodation, tolerance or forbearance? The politics of representing Ethiopia's religious past". Online at: http://www.aegis-eu.org/archive/ecas4/ecas4/panels/41-60/panel-43/Dereje-Feyissa-Dori-Full-paper.pdf

25 Hussein, "Coexistence and/or confrontation?", 5.

26 Hussein, "Coexistence and/or confrontation?", 6. 
towards the Muslims responsible for the decline of the Golden Age culminating in the ultimate domination of Muslims by Christians.

Third, the eighteenth and nineteenth centuries are cited as another period of Muslim dynasties of Warra Himano and Yajju in Wollo in north central Ethiopia. ${ }^{27}$ The narrative celebrates the leaders of these dynasties as "devout Muslims committed to the enhancement of Islam at the regional level and generous patrons to the ulama (religious scholars). They encouraged the teaching of Islam in the royal courts and throughout their territories." ${ }^{28}$ The encounter between trans-regional Muslim traders and contemporary Muslim thinkers and reformers is used to account for the development of "organized resistance to the forced imposition of Christianity - led by nineteenth-century militant Muslim scholars in Wallo". ${ }^{29}$ Such encounter is regarded as positive and liberating. This narrative employs the logic of difference to idealise Islamic rule over that of Christian rule - the former's commitment to is said to have followed a less or non- Evangelism coercive means through mystical orders, whereas the latter's efforts are regarded as coercive (e.g. the reign of Emperor Yohannes IV between 1872 and 1889)..$^{30}$

Fourth, the narrative inscribes the Muslim subject as being caught in a series of conspiracies and subjugations by successive regimes. Lost opportunities such as the reign of Lej Iyyāsu (1913-16) who was pro-Muslim and who sought to "accommodate and integrate Ethiopian Muslims;" and the Italian occupation of Ethiopia (1936-1941) are cited. ${ }^{31}$ The overthrow of Lej Iyyasu and the "harsh measures" 32 against Muslim leaders after the restoration of the monarchy in 1941 resulted in the eclipse of any emerging Muslim. Although the imperial regime allowed Islamic courts to function, "Muslims continued to be secondclass citizens" during the rule of Haile Selassie. ${ }^{33}$

In this narrative, we encounter a reading of the 1974 Ethiopian revolution as a revolt of Muslims and other marginalised groups. Nevertheless, the narrative asserts that the changes instigated by the revolution were not radical enough to significantly affect the fate of Muslims. The period from 1974 to 1991 is considered as the first phase of Islamic revival, and 1991 to the present as the second phase of Islamic revival in Ethiopia. ${ }^{34}$ However, both governments are criticised for failing to adequately respond to Muslim concessions. In this context, it is argued that although Islam has enjoyed legal recognition and has

\footnotetext{
27 Hussein, "Coexistence and/or confrontation?", 7.

28 Hussein, "Coexistence and/or confrontation?", 7.

29 Hussein, "Coexistence and/or confrontation?", 7-8.

30 Hussein, "Coexistence and/or confrontation?", 8.

31 Hussein, "Coexistence and/or confrontation?", 7-9.

32 Hussein, "Coexistence and/or confrontation?", 9.

33 Hussein, "Coexistence and/or confrontation?", 10.

34 Hussein, "Coexistence and/or confrontation?", 10-18.
} 
gained greater visibility in the public sphere, what has been achieved thus far is deemed as insufficient. ${ }^{35}$

Generally, the narrative laments that Muslims were victimised under successive regimes and are still suspected of having relations with external radical groups. Ahmad Hussien draws attention to various localised moments of conflict between Christians and Muslims and the competitions, contentions and polemical exchanges between leaders and lay adherents of the two religions and the intervention of the government in order to precipitate issues of inequality. The situation is further complicated by the contemporary discourse of terrorism, as the result of which Muslims are now policed and placed under continued surveillance. Therefore, the Muslim subject is now under the threat of securitisation, and of losing its recognition and respect.

At this point, I would like to offer some critical remarks beginning with a critique of the new trend of self-writing (i.e. writing about oneself or one's history by oneself), which leads to radical subjectivity. Its resonance remains self-absorbed (in-group or in-tradition tendency) leading to a psychology of distrust, a paranoid relation to the other. In the narrative of Muslim victimisation discussed above, anachronistic historical reconstruction is being undertaken without sufficient attention being given to contextual interpretation. Consequently, it becomes guilty of reading past history using present lenses. Moreover, although the multiple meaning-makings are not as such a negative development, the absence of epistemic humility that should accompany such endeavours is quite disturbing. Most of all, while self-assertion - as an enactment of equality in solidarity with others - is not wrong in itself, the triumphalist undercurrent to win inevitably seems to damage the reciprocity between the Muslim-self and the non-Muslim-other.

Second, in this narrative, binary categories - Christians versus Muslims - are evoked not to challenge strains of relations, but rather to account for moments of the absence of peaceful cohabitation. The juxtaposition of these categories maps onto political identities thereby rendering Ethiopian history as a history of war between Christians and Muslims. The purpose of such juxtaposition is not to offer a myth of religious wars that provides justification for the rise of modern states, as was the case in Europe, but rather to show the historical disadvantages of Muslims in Ethiopia. ${ }^{36}$ In order to assert that Muslims are marginalised, should Muslim scholars create binary categories that reduce the entire history of Ethiopians to that of conflict? I would argue that simply demonstrating the constraints hampering ideas of consensus and cohabitation cannot in itself be constructive.

Third, the narrative is caught in the tension between victimisation and voluntarism. In the struggle for the religious freedom of Muslims, two

35 Hussein, "Coexistence and/or confrontation?", 18-20.

36 Cavanaugh WT. 2009. The Myth of Religious Violence. Oxford: Oxford University Press. 


\section{Religion, Pluralism and Heritage in Ethiopia}

categories are being mobilised: the figure of the Muslim-self as victimised and the assertion of Islamic power (heroism). In the narrative, we find a reading of the Muslim self as victimised and vulnerably exposed to a series of brutal systemic socio-political subjections under successive regimes. It is claimed that the religious identity of Muslims, and its potential as a system of governance, has been historically degraded by Christian Ethiopian rulers. The narrative makes certain aspects remembered, while others are systematically forgotten or muted. To be precise, the narrative makes Muslim victimisation remembered, but Muslim political participation in the Ethiopian state apparatus and Muslim integration and interaction with the Christian people of Ethiopia are systematically explained away, de-emphasised or sometimes denied and ignored altogether.

Finally, although the narrative rehearses a number of historical and contemporary violent incidents, violence itself is not subjected to any kind of critique. Undeniably, the narrative is completely silent on Islamic radicalisation that has been a factor for securitisation (Islam vis-à-vis the state) and the evolvement of an internal caesura within Islam dividing adherents of indigenous Islam and radical groups. In an ideological manoeuvring, it simply reverberates an idea of Muslim homogeneity. It justifies historical acts of violence by Muslim agents as acts of resistance or struggle against marginalisation. In the process, the narrative systematically bypasses the moral question of violence. Consequently, it becomes obvious that the mobilisation of the figure of the Muslim victim is a rhetorical device to advance questions of entitlement and hold onto triumphalism, which manifests in rivalries between Christians and Muslims.

\section{Discursive disrespect as manifest incivility}

Historical discourses are not only the focus of the scholarly domain, but are also constitutive of popular level narratives and polemical exchanges. According to Anwar Mehammed, who examined the Salafi movement in Addis Ababa, "The historical discourse also became the basis for the Salafi interaction and relations with Christians." 37 The historical narrative appears to be a powerful rhetorical device in the hands of the Salafis for it instigates both victimhood and voluntarism. To be sure, the victimisation of Ethiopian Muslims is remembered in order to mobilise Muslims to a struggle - a struggle aimed at reversing past "subservience."

Current practices reveal the fact that there are pervasive rivalries between the opposing groups - Christians and Muslims - that strive to control space (building mosques, churches, media representation) and time (public celebrations, historical

37 Berhem AM. 2015. The Salafi Movement in Islam: An Examination of the Development of its Teaching in Addis Ababa with Special Reference to its Effect on Christian-Muslim Relations, MTh Thesis, Ethiopian Graduate School of Theology, 90. 
national narratives). ${ }^{38}$ What takes centre-stage in such processes are polemical exchanges between Christians and Muslims, which are symptomatic of the crisis of civility. Such polemical exchanges can be captured by the following sample derogative words used by both Muslims and Christians against each other: ${ }^{39}$

By Christians:

"The Strange [Hazardous] Quran"

"... the vagabonding Quran"

"If one looks at the Quran, it is not the word of the creator, but a military camp of terrorists"

By Muslims:

"kufār, infidels"

"Life without power is meaningless ... the disastrous striking arms of

Cain against the meek Abel should be gathered by power"

"... the enemies of Islam of our times"

Such exchanges have a negative impact on Christian-Muslim relations: "This grievance [is] combined with competition for public visibility," and consequently, the "aspiration for political dominance of the Salafi Muslims played a key role in the deterioration of the legacy of peaceful coexistence of different faith communities in Addis Ababa." 40 The vectors of the Salafi Muslims entertain a vision of creating "a homogenous and unified community" as a consequence of which they "denounce other Muslims as munafiq, meaning hypocrites, and Christians as kufār, meaning infidels." ${ }^{41}$ Polemical exchanges via social media reveal a new trend of incivility that derides local practices of peaceful coexistence.

Anwar affirms that "The Salafi movement is often associated with intolerance and violence towards local culture while other Ethiopian Muslims are generally tolerant and nonviolent." He continues, "This development of intolerance

38 Abbink J. 2011. "Religion in Public Spaces: Emerging Muslim-Christian Polemics in Ethiopia", African Affairs 110:2.

39 These exchanges appear in the essay written by Abakiya B. 2012. "Brief Review of Books Written in the Amharic Language Focusing on Christian-Muslim Relations in Ethiopia with Reference to Their Role in Strengthening Peaceful ChristianMuslim Relations", in Proceedings of the Academic Consultation on Christian Muslim Relations in Ethiopia (Amharic and English), Addis Ababa, 1-5 August 2011; Klein J. 2005. The Ethiopian Evangelical Church Mekane Yesus and Its Understanding of Islam and Approaches to Muslims in Ethiopia from 1969-2004, MPhil Thesis, Missionsseminar Hermannsburg (Germany), 212-231.

40 Berhem, The Salafi Movement in Islam, 65. For an account of peaceful coexistence in Addis Ababa, confer to the study conducted by Beyene A. 2009. Religious Tolerance in Addis Ababa, 1991-2008, Master's Thesis, Institute of Ethiopian Studies, Addis Ababa University.

41 Berhem, The Salafi Movement in Islam, 66. 


\section{Religion, Pluralism and Heritage in Ethiopia}

towards local culture gave rise to the conflict between the Salafis and other Muslims." 42 Many Muslims, for example, contend against "the Arabization of their society" with respect to dress codes and the "Salafis' rejection of the Maulid". ${ }^{43}$ Above all, the "insulting" and "provoking" of Christians by the Salafis instigates violence and intolerance between Christians and Muslims. ${ }^{44}$ Of course, the focus on discursive disrespect as manifest incivility is not to deny the existence of spectacular violence, as expressed in the mutilation and killing of people and burning of churches. This situation demands a focus on an ethic of togetherness in which themes such as cohabitation and responsibility are figured in.

\section{TOWARDS A MORAL PEDAGOGY OF COHABITATION AND RESPONSIBILITY}

So far, we have seen where we are in relation to new religious developments and old heritage. Where, then, does this discussion lead us? As a preface to my answer, I must note that the idiom of tolerance, as noted above has been exhausted. The language of tolerance strongly depicts the other as an object of hate to be tolerated, and this has an intrinsic incompatibility with the idea of religious pluralism. In this section, I wish to propose "cohabitation" as an alternative to tolerance, and explore its potential to transform the syntax of the public. Let me briefly elaborate the notion of cohabitation using the following three points.

First, the other is conceived as a cohabitor. Cohabitation is about the recognition of the other as a fellow human. World religions teach about welcoming the other. The so-called Golden Rule, which exists in different variants in world religions, is the primordial or fundamental ethic that promotes cohabitation. This rule refers to "the precepts that one should do as one would be done by." ${ }^{45}$ Such rule is considered as an "ethic of reciprocity" and the word "golden" refers to "inestimable utility." ${ }^{46}$ Several religious texts demonstrate the value of the Golden Rule. In the Christian Scripture, Matthew 7:12 is one of the most cited: "whatsoever ye would that men should do to you, do ye even so to them". The rule is not only one that fosters the ethical aim (the good) but also it can be expressed "negatively", (with a deontological tone) as in Hillel (cf. the Babylonian Talmud, Shabbat 31a): "What is hateful to you, do not do to your comrade. This is

42 Berhem, The Salafi Movement in Islam, 71-72.

43 Berhem, The Salafi Movement in Islam, 72.

44 Berhem, The Salafi Movement in Islam, 82, 86, 89.

45 1994. The Chambers Dictionary. New York: Larousse, 718.

46 1996. The Compact Edition of the Oxford English Dictionary. Oxford: Oxford University Press, 188. See also Green WS. 2008. "Parsing Reciprocity: Questions for the Golden Rule", in Neusner J and Chilton BD (eds). The Golden Rule: The Ethics of Reciprocity in World Religions. London \& New York: Continuum, 1. 
the entire Torah. And the rest is commentary. Go and study." 47 We recognise that the Golden Rule has both positive ("Do" unto others) and negative ("Do not do" unto others) formulations.

The Golden Rule exemplifies a religiously-base moral virtue that reminds one of the humanity of the other - that is, the other human being is like oneself and one should not dream of living without the other. The advantage of the Golden Rule is its unique universal accessibility and simplicity. Jeffrey Wattles, professor of philosophy notes:

The golden rule is, from the first, intuitively accessible, easy to understand; its simplicity communicates confidence that the agent can find the right way. The rule tends to function as a simplified summary of the advocate's moral tradition, and it most commonly expresses a commitment to treating others with consideration and fairness, predicated on the recognition that others are like oneself. ${ }^{48}$

As explicated in the quotation above, the Golden Rule is simple, accessible and is concerned with justice as fairness. The last sentence, in particular, highlights philosopher Paul Ricoeur's notion of "oneself as another" ${ }^{49}$ Even so, there are scholars who question the practicality of the Golden Rule on the basis that it cannot offer a clear guidance in ethical and practical conduct. Critics argue that the Golden Rule is too general and plastic insofar as two opposing groups inhabiting mutually exclusive moral positions can use it to reach different, often divergent, conclusions. For example, historically, both the pro-slavery as well as the abolitionist preachers used the Golden Rule in their rhetoric, albeit in divergent ways. For abolitionists, the Golden Rule sanctions the elimination of slavery. In contrast, for proslavery ministers, the abolition of slavery might cause the disruption of the social order and the economic system; therefore, the Golden Rule is meant to endure slavery.

Nonetheless, while such a positive ethic of reciprocity might work negatively, I contend that the Golden Rule has a critical and reparative capacity that can shape and inform our ethos, the ethical between, and ultimately the rule of law. The ethical between is the common ethos that binds us together. The ethical between assumes a primal and primordial nature that is intertwined with living together as cohabitants - thereby, manifesting the worth of beings who cohabit. This becomes possible by drawing attention to "the preconditions, contexts, settings, frameworks, stipulations, etc. that give the Golden Rule its concrete and substantive significance." ${ }^{50}$ In the work of Paul Ricoeur, we find

47 Green, "Parsing Reciprocity", 1. For the Golden Rule in Islamic sacred scriptures, see Homerin E. 2008. "The Golden Rule in Islam", in Neusner and Chilton (eds). The Golden Rule, 99-115.

48 Wattles J. 1996. The Golden Rule. Oxford. Oxford University Press, 188 cited in Green, "Parsing Reciprocity", 1.

49 See Ricoeur P. 1992. Oneself as Another. Blamey K (trans). Chicago: Chicago University Press, 218-239.

50 Green, "Parsing Reciprocity", 5. 


\section{Religion, Pluralism and Heritage in Ethiopia}

a philosophically rich argument for how the Golden Rule can be understood within the discourse of self-esteem, respect, juridical-recognition and equality before the law. ${ }^{51}$

Second, cohabitation fosters genuine religious plurality. The "unchosen" nature of cohabitation already assumes heterogeneous peaceful inhabiting of the earth. ${ }^{52}$ The contemporary understanding of religious pluralism - inclusivism juxtaposed against exclusivism - already assumes an implicit homogeneity or sameness of religions. This logic of sameness is embedded in comparative study of religions and some trends of theological studies. Here, a case in point could be the work of philosopher and theologian John Hick who attempts to deride the uniqueness of the incarnation (and hence, the Trinity) in order to demonstrate the sameness or non-uniqueness of Christian religion from others. Such an approach claims to be in support of pluralism - while it is against it implicitly. Cohabitation can avoid such reductive tendency - the reduction of all religions or pluralism by the logic of sameness - within contemporary trends that accentuate pluralism.

Cohabitation is distinct from integration, which inclines towards homogenising multiplicity. It is also distinct from radical exclusivism or difference, which rejects any attempt to explore commonalty. Cohabitation is a midway proposal equidistant from inclusivist integration and exclusivist fundamentalism. Unlike the former, cohabitation encourages claims to uniqueness, and in contrast to the latter, it promotes exploring convergences of history and creating frontiers or sites of commonality. Its modality advances an understanding of politics as an art of togetherness and works contrary to economies of exclusion, on the one hand, and visions of homogenisation, on the other.

Finally, the risk entailed by cohabitation is rather a summons to responsibility. Cohabitation and the spirit of religious pluralism imply that self-esteem and respect will have to be translated into juridical recognition that makes possible religious pluralism and mutual recognition. Concomitant to cohabitation is equal treatment guaranteed by juridical recognition. ${ }^{53}$ Nonetheless, juridical recognition and the rule of law may not be the ultimate solution for a troubled coexistence. There are certain risks involved in practices of cohabitation and in cases of disturbed cohabitation, post-juridical reconciliation has to be in place. All these point towards the necessity of responsibility that must be undertaken by each religious group.

51 Ricoeur, Oneself as Another, 218-239.

52 Bulter, "Is Judaism Zionism?", 84.

53 Ricoeur P. 2005. The Course of Recognition. Cambridge, Massachusetts and London: Harvard University Press, 197-246. 


\section{CONCLUSION}

Social developments in Ethiopia have led to the legal norm of equality in the recognition of all religions. Acts of rights assertion or the enactment of equality, in Ethiopia, as practiced by religions are grounded in the rights and freedoms enshrined in the Ethiopian Constitution. Demands for more concessions problematises the religion-state relations. Here, the Muslim protests in Ethiopia of 2011 that went on for about two years - which eventually became a threat to security - may shed some light. The scope of this study has been delimited to the analysis of narratives. However, narratives of victimisation and marginalisation have the potential to produce even more problems in the public sphere. Unfortunately, the radical imaginations fostering religious identities that operate under the logic of hate-of-the-other neither sanction the rule of law nor cultivate the heritage of mutual respect. The critical notes, forwarded in this essay, on the Muslim narrative of identity are not meant to reject the self-assertion of Muslims, but to critique the inherent and implicit violence underlying that narrative. In the narrative analysed above, we demonstrated the implicit polemic against Christianity.

As a discourse of inversion, Muslim narratives of victimisation and marginalisation draw their categories in contradistinction to the historical narrative of Christian Ethiopia. In doing so, the discourse replicates old opposed binaries (Christian-Muslim) insofar as it - paradoxically - mobilises the figure of the victim and celebrates heroism, in which case the immorality of violence escapes critique. Such victimisation amplifies resentment and replicates violence, and becomes a site for the cultivation of radical imaginations that lead to the crisis of civility. In this chapter, we have focused on discursive disrespect and manifest incivility as an alarm that summons reflective sobriety. The way out of this crisis is through advancing a religiously-informed moral pedagogy of cohabitation and responsibility. 